This Accepted Author Manuscript is copyrighted and published by Elsevier. It is posted here by agreement between Elsevier and University of Brasilia. Changes resulting from the publishing process - such as editing, corrections, structural formatting, and other quality control mechanisms - may not be reflected in this version of the text. The definitive version of the text was subsequently published in [Animal Reproduction Science, Volume 108, Issue 3-4, November 2008, Pages 309-318, doi:10.1016/j.anireprosci.2007.08.016].You may download, copy and otherwise use the AAM for non-commercial purposes provided that your license is limited by the following restrictions:

(1) You may use this AAM for non-commercial purposes only under the terms of the CC-BY-NCND license.

(2) The integrity of the work and identification of the author, copyright owner, and publisher must be preserved in any copy.

(3) You must attribute this AAM in the following format: [agreed attribution language, including link to CC BY-NC-ND license + Digital Object Identifier link to the published journal article on Elsevier's ScienceDirect ${ }^{\circledR}$ platform].

Este Manuscrito do Autor Aceito para Publicação (AAM) é protegido por direitos autorais e publicado pela Elsevier. Ele esta disponível neste Repositório, por acordo entre a Elsevier e a Universidade de Brasília. As alterações decorrentes do processo de publicação - como a edição, correção, formatação estrutural, e outros mecanismos de controle de qualidade - não estão refletidas nesta versão do texto. A versão definitiva do texto foi posteriormente publicado em [Animal Reproduction Science, Volume 108, Número 3-4, Novembro de 2008, Páginas 309-318 doi:10.1016/j.anireprosci.2007.08.016]. Você pode baixar, copiar e utilizar de outra forma o AAM para fins não comerciais, desde que sua licença seja limitada pelas seguintes restrições: (1) Você pode usar este AAM para fins não comerciais apenas sob os termos da licença CC- BYNC-ND.

(2) A integridade do trabalho e identificação do autor, detentor dos direitos autorais e editor deve ser preservado em qualquer cópia.

(3) Tem de atribuir este AAM no seguinte formato: [acordo na linguagem atribuída, incluindo o link para CC BY-NC-ND licença Digital + DOI do artigo publicado na revista Elsevier ScienceDirect ${ }^{\circledR}$ da plataforma]. 


\title{
Preservation of bovine preantral follicle viability and ultra-structure after cooling and freezing of ovarian tissue
}

\author{
Juliana Jales de Hollanda Celestino \\ Regiane Rodrigues dos Santos \\ Cláudio Afonso Pinho Lopes \\ Fabrício Sousa Martins \\ Maria Helena Tavares Matos \\ Mônica Aline Parente Melo \\ Sônia Nair Báo \\ Ana Paula Ribeiro Rodrigues \\ José Roberto Viana Silva \\ José Ricardo de Figueiredo
}

\begin{abstract}
Bovine preantral follicles within ovarian fragments were exposed and cryopreserved in absence or presence of $1.5 \mathrm{M}$ glycerol (GLY), ethylene glycol (EG), propanediol (PROH) or dimethyl sulfoxide (DMSO), undergoing a previous cooling at $20^{\circ} \mathrm{C}$ for $1 \mathrm{~h}$ (protocol 1 ) or at 4 ${ }^{\circ} \mathrm{C}$ for $24 \mathrm{~h}$ (protocol 2) in $0.9 \%$ saline solution. At the end of each treatment, preantral follicles were classified as non-viable/viable when they were stained/not stained with trypan blue, respectively. To confirm viability staining, ultra-structure of the follicles was evaluated by transmission electronic microscopy (TEM). Data were compared by Chi-square test $(\mathrm{P}<0.05)$. The storage of the ovaries at $20^{\circ} \mathrm{C}$ for $1 \mathrm{~h}(78 \%)$ and $4{ }^{\circ} \mathrm{C}$ for $24 \mathrm{~h}(80 \%)$ did not reduce significantly the percentage of viable preantral follicles when compared to the control (75\%). Similar results were obtained when ovarian fragments, respectively, for protocols 1 and 2, were exposed to MEM (78 and 77\%), 1.5 M EG (78 and 71\%), as well as frozen in 1.5 M EG (74 and $77 \%)$. Percentages of viable follicles in control were similar to those observed after exposure (75\%) and freezing (76\%) in presence of $1.5 \mathrm{M}$ DMSO only when protocol 1 was used. The increase of the concentration from 1.5 to $3.0 \mathrm{M}$, for all cryoprotectants, reduced significantly the percentage of viable preantral follicles after freezing. Ultra-structural analysis has confirmed trypan blue results, showing that not only basement membrane, but also organelles, were intact in viable preantral follicles. In conclusion, ovarian tissue cooling at $4{ }^{\circ} \mathrm{C}$ for $24 \mathrm{~h}$ before cryopreservation (protocol 2 ) does not affect the viability of bovine preantral follicles when 1.5 M EG is present in the cryopreservation medium.
\end{abstract}

Keywords: Cooling; Freezing; Viability; Preantral follicles; Bovine

\section{Introduction}

Cows are present in all continents, and are commercially highly attractive livestock animals since they can be used for many purposes such as milk, meat and skin production. Therefore, studies in bovine reproduction and preservation have become important because, regarding folliculogenesis, human ovaries have more similarities with bovine ones than those from mice (Paynter et al., 1999 and Gandolfi et al., 2006).

The ultimate aim of ovarian cryopreservation is to store developmentally competent follicles. Studies using bovine frozen-thawed preantral follicles have shown that not always 
histological morphology is confirmed by ultra-structural analysis (Lucci et al., 2004a). The use of histology alone is insufficient to assess the freezing-thawing process as morphological analysis, and is often not correlated to the viability or developmental competence of the follicles (Santos et al., 2006a and Santos et al., 2007a). Transmission electronic microscopy (TEM) is an important tool to assess the cell quality after freezing-thawing, because cryopreservation often induces loss of cell contents (Rodrigues et al., 2004a) and loss of mitochondrial activity (Santos et al., 2006b). In studies using ovine embryos as model, Cocero et al. (2002) showed damage in organelles, at the ultra-structural level, from apparently normal cells.

Most of the preservation protocols for ovarian tissue have been performed in presence of permeable cryoprotective substances such as glycerol (GLY), ethylene glycol (EG), propanediol (PROH) and dimethyl sulfoxide (DMSO), in concentrations ranging from 1.5 to 3.0 M. Besides their cryoprotective effect, these substances can also be toxic to cells, mainly during exposure period (Rodrigues et al., 2004a, Rodrigues et al., 2004b and Santos et al., 2007b). Therefore, attention must be given to ovary transport before cryopreservation procedures. We have a standard protocol for ovarian transport $\left(20{ }^{\circ} \mathrm{C}\right.$ for $1 \mathrm{~h}$ ), after which ovaries are submitted to exposure and cryopreservation. However, sometimes donor animals are far away from laboratories and transport takes hours, being indicated to keep ovarian tissue at $4{ }^{\circ} \mathrm{C}$ for up to $24 \mathrm{~h}$ in $0.9 \%$ saline solution (Celestino et al., 2007). Nevertheless, it is still unknown if long-term cooling have influence on the success of cryopreservation.

The aim of this study was determine a freeze-thaw procedure that better preserves the viability and ultra-structure of bovine preantral follicles, even after long-term ( $24 \mathrm{~h}$ ) storage of the ovarian tissue at low-temperature $\left(4{ }^{\circ} \mathrm{C}\right)$. Studies have been performed with fresh (maximum of $1 \mathrm{~h}$ after animal slaughter) and stored ovarian fragments that were exposed to or cryopreserved by using 1.5 or 3.0 M GLY, EG, PROH and DMSO. Viability and ultra-structure of preantral follicles were investigated by using trypan blue and TEM, respectively.

\section{Material and methods}

\subsection{Source and preparation of ovarian tissue}

Reproductive organs $(n=10)$ from adult mixed breed cows were obtained at a local slaughterhouse (Multi-carnes, Fortaleza-CE, Brazil). The ovaries were trimmed of adhering tissue, washed in $70 \%$ alcohol, twice in $0.9 \%$ saline solution, and then immediately transported 
to the laboratory $(\sim 1 \mathrm{~h})$ in thermo flasks containing tubes filled with $0.9 \%$ saline solution at 20 or $4{ }^{\circ} \mathrm{C}$.

\subsection{Experimental design}

From each ovarian pair, one fragment of $3 \mathrm{~mm} \times 3 \mathrm{~mm} \times 1 \mathrm{~mm}$ was collected (control) and immediately fixed in Carnoy's fluid for $12 \mathrm{~h}$ for routine histological studies. Another fragment of $1 \mathrm{~mm} 3$ was fixed in paraformaldehyde/glutaraldehyde solution (paraformaldehyde $2 \%$ and glutaraldehyde $2.5 \%$ in sodium cacodylate buffer $0.1 \mathrm{M}, \mathrm{pH} 7.2$ ) for TEM. From each ovarian pair, one ovary was kept in $0.9 \%$ saline solution at $20{ }^{\circ} \mathrm{C}$ for $1 \mathrm{~h}$ (standard protocol used in our laboratory for ovaries transport-protocol 1) and the other was maintained in the same solution at $4{ }^{\circ} \mathrm{C}$ for $24 \mathrm{~h}$ (cooling before cryopreservation-protocol 2 , Celestino et al., 2007). Subsequently, each ovary was divided into 19 fragments of $3 \mathrm{~mm} \times 3$ $\mathrm{mm} \times 1 \mathrm{~mm}$ and subdivided as follows: (i) one fragment was submitted to follicular isolation, applying a mechanical procedure for the isolation of bovine preantral follicles as described by Figueiredo et al. (1993); (ii) nine fragments were exposed to MEM alone $(n=1)$, or to 1.5 or 3.0 M of DMSO ( $n=2)$, EG $(n=2), \operatorname{GLY}(n=2)$ or PROH $(n=2)$; and (iii) nine fragments were cryopreserved in presence of MEM alone $(n=1)$, or to 1.5 or 3.0 M of DMSO $(n=2), \operatorname{EG}(n=2)$, GLY $(n=2)$ or PROH $(n=2)$. At the end of each treatment, $1 \mathrm{~mm} 3$ of each fragment was fixed for TEM, and the remaining ovarian piece was submitted to follicular isolation and aliquots were analyzed (see experimental protocol at Fig. 1).

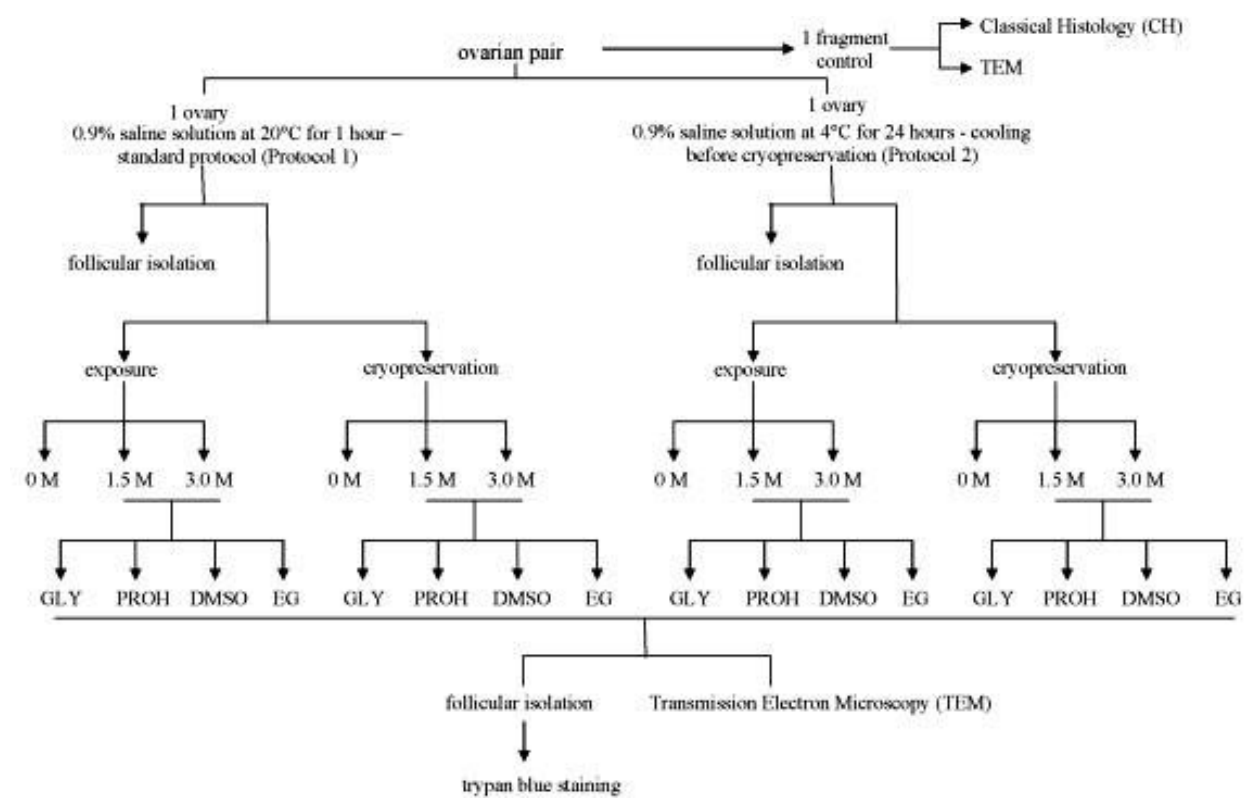

Fig. 1. Experimental protocol for cooling in $0.9 \%$ saline solution, exposure and cryopreservation of bovine preantral follicles. 


\subsection{Cryoprotectant exposure (toxicity test) and freezing-thawing procedure}

For cryoprotectant exposure, the cryoprotectant addition was made in one step as follows: ovarian fragments were placed individually in cryovials and equilibrated in $1.8 \mathrm{ml}$ MEM added or not by 1.5 or $3.0 \mathrm{M}$ DMSO, EG, GLY or PROH at $20{ }^{\circ} \mathrm{C}$ for $20 \mathrm{~min}$. After equilibration, the cryoprotectant was removed. Cryoprotectant removal was performed according to the method described by Candy et al. (1997). Briefly, the cryoprotectant was removed from the tissue at room temperature using a three-step equilibration ( $5 \mathrm{~min}$ each) in MEM supplemented with $10 \%$ fetal bovine serum (MEM+). Finally, the ovarian fragments were submitted to follicular isolation.

For freezing, ovarian fragments were equilibrated (exposed to cryoprotectants as described in the previous paragraph) and submitted to a cryopreservation protocol. For this, after equilibration, cryovials were placed in a controlled-rate programmable freezer (Freeze Control, Cryologic Pty Ltd., Waverley, Australia) at $20^{\circ} \mathrm{C}$. Cryovials were cooled at $2{ }^{\circ} \mathrm{C} / \mathrm{min}$ from 20 to $-7^{\circ} \mathrm{C}$; ice-induction (seeding) was manually performed by touching the vials with forceps pre-cooled in liquid nitrogen. After seeding, the vials were held at $-7^{\circ} \mathrm{C}$ for $10 \mathrm{~min}$ and then cooled at $0.3{ }^{\circ} \mathrm{C} / \mathrm{min}$ to $-30^{\circ} \mathrm{C}$ and finally at $0.15{ }^{\circ} \mathrm{C} / \mathrm{min}$ to $-33^{\circ} \mathrm{C}$, after which the vials were immersed into liquid nitrogen $\left(-196^{\circ} \mathrm{C}\right)$ and stored for 5 days.

When required, the samples were thawed in air for $1 \mathrm{~min}$ at room temperature ( 25 ${ }^{\circ} \mathrm{C}$ ) and then immersed in a water bath at $37{ }^{\circ} \mathrm{C}$ until the cryopreservation medium was completely melted. The cryoprotectant was removed according to the procedure described above.

\subsection{Follicular isolation, trypan blue staining and assessment of follicular viability}

Bovine preantral follicles were isolated from ovarian tissue by applying a mechanical procedure for the isolation of bovine follicles as described by Figueiredo et al. (1993). Briefly, the ovarian cortex was cut into small fragments using a tissue chopper (The Mickle Laboratory Engineering Co., Gomshal, Surrey, UK). The ovarian fragments were then placed in MEM+ and then pipetted 40 times with a large Pasteur pipette (diameter $\sim 1600 \mu \mathrm{m}$ ) and, subsequently, 40 times with a smaller pipette (diameter $\sim 600 \mu \mathrm{m}$ ) to release the preantral follicles. The suspension was successively filtered through 500 and $100 \mu \mathrm{m}$ nylon-mesh filters. Isolated preantral follicles were transferred to $300 \mu \mathrm{l}$ MEM+ with addition of $15 \mu$ trypan blue $0.4 \%$ and incubated for $1 \mathrm{~min}$. Follicles were scored as viable when unstained and non-viable when stained with trypan blue (Fig. 2), and the percentages of viable follicles calculated. 


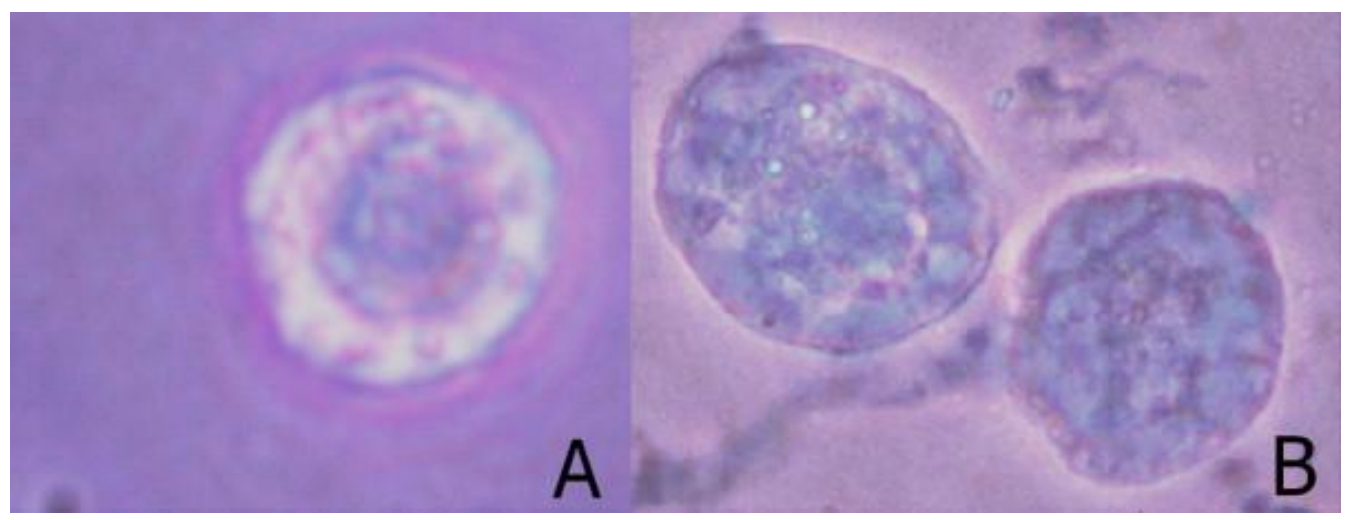

Fig. 2. Bovine preantral follicles submitted to trypan blue staining. Uptake of trypan blue stain or not is indicative of a non-viable or viable follicle, respectively $(400 \times)$. (For interpretation of the references to color in this figure legend, the reader is referred to the web version of the article.)

\subsection{Ultra-structural analysis}

For a better evaluation of the follicular quality, ultra-structural analysis was performed on follicles from treatments that gave similar results than the control treatment in terms of follicular viability. Briefly, small pieces of ovarian cortex with a maximum dimension of $1 \mathrm{~mm} 3$ were fixed in a solution containing $2 \%$ paraformaldehyde and $2.5 \%$ glutaraldehyde in $0.1 \mathrm{M}$ sodium cacodylate buffer $(\mathrm{pH} 7.2)$. After fixation, specimens were rinsed in buffer and postfixed in $1 \%$ osmium tetroxide, $0.8 \%$ potassium ferricyanide and $5 \mathrm{mM} \mathrm{CaCl} 2$ in $0.1 \mathrm{M}$ sodium cacodylate buffer. Subsequently, samples were dehydrated in acetone and embedded in Spurr's epoxy resin. Semi-thin sections $(3 \mu \mathrm{m})$ were cut and stained with toluidine blue. Only follicles classified as morphologically normal in semi-thin sections were evaluated. Ultra-thin sections $(80 \mathrm{~nm})$ were prepared from samples when the oocyte nucleus was present in the semi-thin sections. Ultra-thin sections were contrasted with uranyl acetate and lead citrate, and examined using a JEOL $1100 \mathrm{C}$ (JEOL, Tokyo, Japan) transmission electron microscope.

\subsection{Statistical analysis}

Percentages of viable follicles obtained in the different follicular treatments were compared with those from controls using a Chi-square test. All data were submitted to ANOVA using a factorial design (temperature of transport, cryoprotectant and cryopreservation effect). Data were compared by the Tukey-Kramer test. Values were considered statistically significant when $\mathrm{P}<0.05$. 


\section{Results}

Bovine preantral follicles were examined for their viability and, based on the absence of trypan blue staining, the percentages of viable follicles were calculated (Table 1 and Table 2). The percentages of viable preantral follicles at control, after ovarian transport at $20^{\circ} \mathrm{C}$ for 1 $\mathrm{h}$ (protocol 1) as well as ovarian storage at $4{ }^{\circ} \mathrm{C}$ for $24 \mathrm{~h}$ (protocol 2), were not significantly different among each other, showing that cooling did not affect follicular viability.

Table 1

Percentages (viable/total) of viable preantral follicles in control ovarian fragments and in fragments that were exposed or cryopreserved in DMSO or EG with or without previous cooling.

\begin{tabular}{|c|c|c|c|c|c|}
\hline & & \multicolumn{2}{|c|}{$20^{\circ} \mathrm{C}$ for $1 \mathrm{~h}$ (standard-protocol 1 ) } & \multicolumn{2}{|c|}{$4^{\circ} \mathrm{C}$ for $24 \mathrm{~h}$ (protocol 2 ) } \\
\hline & & Exposure & Cryopreservation & Exposure & Cryopreservation \\
\hline $0 \mathrm{M}$ & & $74 \mathrm{aA}(121 / 163)$ & $14^{*} \mathrm{bA}(23 / 168)$ & $77 \mathrm{aA}(137 / 177)$ & $9 * \mathrm{bA}(15 / 159)$ \\
\hline DMSO & $\begin{array}{l}1.5 \mathrm{M} \\
3.0 \mathrm{M}\end{array}$ & $\begin{array}{l}75 \mathrm{aA}(121 / 161) \\
39 * \mathrm{aA}(65 / 169)\end{array}$ & $\begin{array}{l}76 \mathrm{afA}(127 / 167) \\
42^{*} \mathrm{aA}(68 / 164)\end{array}$ & $\begin{array}{l}62 * \mathrm{aB}(106 / 172) \\
39 * \mathrm{aA}(65 / 167)\end{array}$ & $\begin{array}{l}67^{*} \mathrm{aB}(109 / 163) \\
4^{\bullet} \mathrm{bB}(81 / 167)\end{array}$ \\
\hline EG & $\begin{array}{l}1.5 \mathrm{M} \\
3.0 \mathrm{M}\end{array}$ & $\begin{array}{l}78 \mathrm{aA}(128 / 165) \\
53^{*} \mathrm{aA}(88 / 167)\end{array}$ & $\begin{array}{l}74 \mathrm{aA}(119 / 162) \\
43^{*} \mathrm{aA}(74 / 171)\end{array}$ & $\begin{array}{l}71 \mathrm{aA}(121 / 171) \\
62^{*} \mathrm{aB}(102 / 165)\end{array}$ & $\begin{array}{l}77 \mathrm{aA}(135 / 176) \\
43^{\circ} \mathrm{bA}(72 / 167)\end{array}$ \\
\hline Control & & & $75(120$ & & \\
\hline
\end{tabular}

$(*)$ Differs significantly from control $(P<0.05)$; $(a$ and $b)$ values within rows are significantly different comparing exposure and cryopreservation $(P<0.05)$ from each group; $(A$ and $B)$ values within rows are significantly different within exposure and cryopreservation between groups (with or without previous cooling at $\left.4{ }^{\circ} \mathrm{C}, \mathrm{P}<0.05\right)$.

Table 2

Percentages (viable/total) of viable preantral follicles in control ovarian fragments and in fragments that were exposed or cryopreserved in GLY or PROH with or without previous cooling

\begin{tabular}{|c|c|c|c|c|c|}
\hline & & \multicolumn{2}{|c|}{$20^{\circ} \mathrm{C}$ for $1 \mathrm{~h}$ (standard-protocol 1 ) } & \multicolumn{2}{|c|}{$4^{\circ} \mathrm{C}$ for $24 \mathrm{~h}$ (protocol 2$)$} \\
\hline & & Exposure & Cryopreservation & Exposure & Cryopreservation \\
\hline $0 \mathrm{M}$ & & $74 \mathrm{aA}(121 / 163)$ & $14^{*} \mathrm{bA}(23 / 168)$ & $77 \mathrm{aA}(137 / 177)$ & $9 * \mathrm{bA}(15 / 159)$ \\
\hline GLY & $\begin{array}{l}1.5 \mathrm{M} \\
3.0 \mathrm{M}\end{array}$ & $\begin{array}{l}34^{*} \mathrm{aA}(56 / 166) \\
23^{*} \mathrm{aA}(38 / 163)\end{array}$ & $\begin{array}{l}42^{*} \mathrm{aA}(69 / 164) \\
34^{*} \mathrm{aA}(57 / 170)\end{array}$ & $\begin{array}{l}45^{\bullet} \mathrm{aB}(73 / 163) \\
4^{\bullet} \mathrm{aB}(71 / 161)\end{array}$ & $\begin{array}{l}49^{*} \mathrm{aB}(82 / 166) \\
37^{\circ} \mathrm{aA}(64 / 172)\end{array}$ \\
\hline PROH & $\begin{array}{l}1.5 \mathrm{M} \\
3.0 \mathrm{M}\end{array}$ & $\begin{array}{l}52 * a A(86 / 164) \\
39 *_{a A}(65 / 168)\end{array}$ & $\begin{array}{l}48 * \mathrm{aA}(79 / 166) \\
36 * \mathrm{aA}(60 / 167)\end{array}$ & $\begin{array}{l}59^{\circ} \mathrm{aB}(96 / 165) \\
52^{\circ} \mathrm{aB}(90 / 173)\end{array}$ & $\begin{array}{l}45^{\circ} \mathrm{bA}(74 / 164) \\
34^{\circ} \mathrm{bA}(55 / 164)\end{array}$ \\
\hline Control & & & $75(120) 1$ & & \\
\hline
\end{tabular}

$(*)$ Differs significantly from control $(\mathrm{P}<0.05)$; $(\mathrm{a}$ and $\mathrm{b})$ values within rows are significantly different comparing exposure and cryopreservation $(P<0.05)$ from each group; $(A$ and $B)$ values within rows are significantly different within exposure and cryopreservation between groups (with or without previous cooling at $\left.4{ }^{\circ} \mathrm{C}, \mathrm{P}<0.05\right)$.

Exposure of preantral follicles previously submitted to protocol 1, kept viability percentages similar to control values only when MEM was used alone, added by $1.5 \mathrm{M}$ DMSO or 1.5 M EG. Similar results were observed for follicles submitted to protocol 2, except for 1.5 M DMSO, which led to a significant decrease in follicular viability when compared to control and 1.5 M EG (Table 1).

Likewise after follicular exposure, cryopreservation of follicles previously submitted to protocol 1 (only for 1.5 M DMSO or EG) and protocol 2 (only for 1.5 M EG) did not decrease significantly the percentage of viable follicles when compared to control (Table 1). When 
cryopreservation was performed in presence of GLY or PROH, it was observed a significant reduction of viable preantral follicles (Table 2). This deleterious effect was higher when no cryoprotectant was used.

For both protocols, after exposure and cryopreservation, increase in cryoprotectant concentration led to a significant decrease in the percentages of viable preantral follicles. When protocol 1 and 2 were compared to each other, a higher percentage of viable follicles after cryopreservation (1.5 M GLY or 3.0 M DMSO) was observed in the follicles from protocol 2. In contrast, significant higher percentage of viable follicles from protocol 1 was observed after exposure and cryopreservation in presence of 1.5 M DMSO.

Results obtained after cryopreservation using 1.5 M EG (both protocols) or $1.5 \mathrm{M}$ DMSO (protocol 1) were confirmed by ultra-structural analysis (see Fig. 3), which was performed only for preantral follicles that were considered as normal in semi-thin sections stained with toluidine blue. Normal preantral follicles presented a large oocyte with welldelimited nucleus, large round mitochondria, with irregular cristae and continuous mitochondrial membranes and elongated mitochondria with parallel cristae (Fig. 3A-control; 3B-after cooling; 3C-frozen follicles in presence of $1.5 \mathrm{M} \mathrm{EG}$ using both protocols; 3Dfrozen follicles in presence of 1.5 M DMSO using protocol 1). These follicles furthermore exhibit some electron-dense granules and both smooth and rough endoplasmic reticulum, either as isolated aggregations or as complex associations with mitochondria and vesicles. Granulosa cells around these oocytes had irregularly shaped nuclei, with a high nucleus-tocytoplasm ratio. Some follicles from control group (Fig. 4A) or those ones frozen in $1.5 \mathrm{M}$ DMSO with previous cooling using protocol 2 (Fig. 4B), seemed to be well preserved in semithin toluidine blue stained sections. Ultra-structurally, however, these follicles appeared to have an extremely vacuolated oocyte (Fig. 4A and B). In some cases, fusion of these vacuoles had caused the presence of empty cytoplasmic areas. Occasionally, this alteration was associated with loss of granulosa cell content and, in some cases, with oocyte nuclear shrinkage. Furthermore, granulosa cells were slightly swollen, with a low density of organelles present in their cytoplasm. Some granulosa cells had disappeared, leaving a vacuolated space. In some degenerating follicles, oocyte nucleus could not be recognized and some apoptotic bodies were present. 

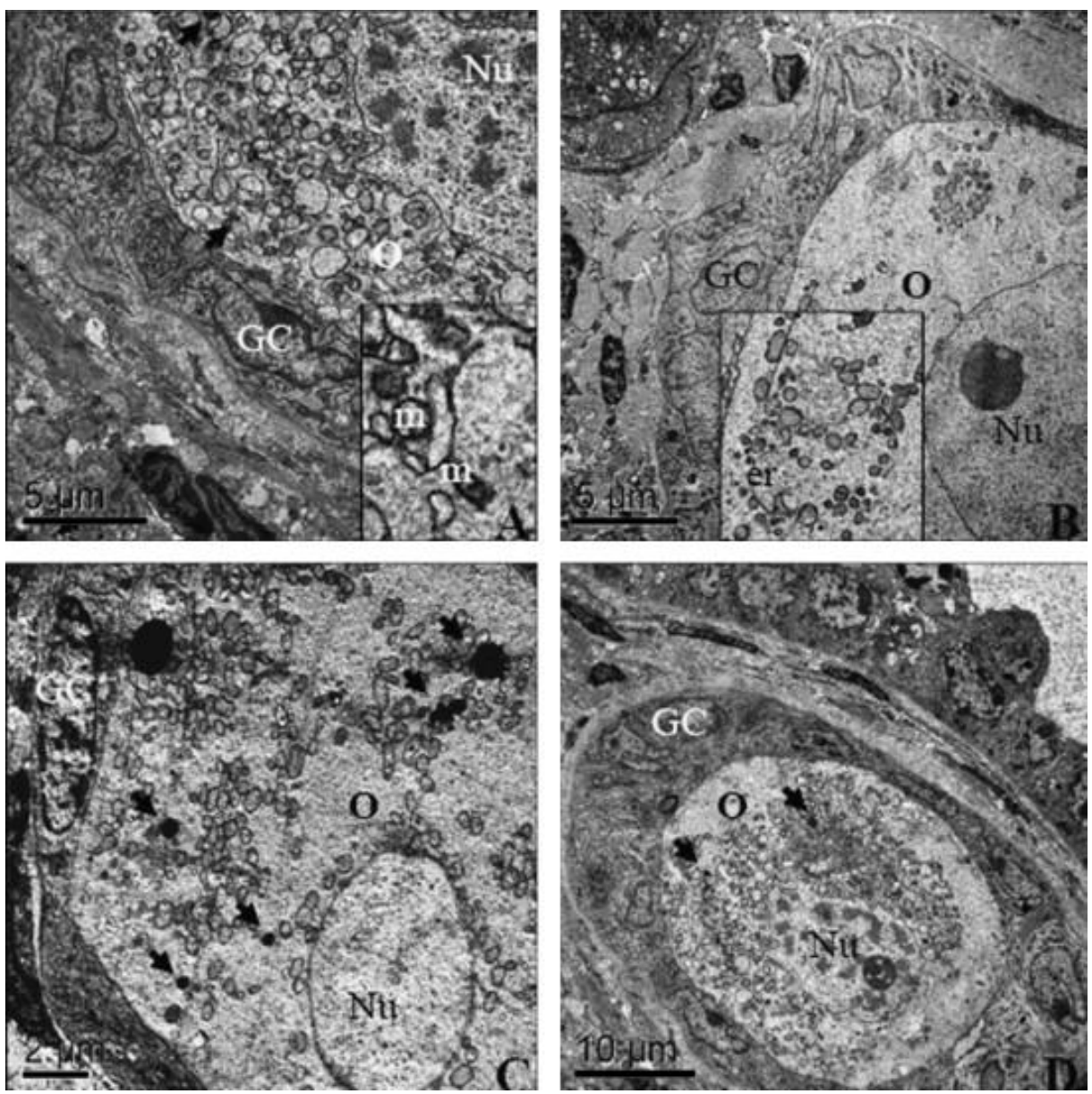

Fig. 3. Ultra-structural analysis of fresh ovarian tissue (control group)-A; cooled at $4{ }^{\circ} \mathrm{C}$ for 24 $\mathrm{h}-\mathrm{B}$; frozen in presence of 1.5 M EG independent of the protocol-C; frozen in presence of 1.5 M DMSO using protocol 1-D. O, oocyte; Nu, nucleus; GC, granulosa cell; m, mitochondria; er, endoplasmic reticulum. Note the chromatin uncondensed at $A$ and $D$, and some electrondense granules at $A-C$ (see arrows). (A and B: 5000x, bar $=5 \mu \mathrm{m} ; C: 12000 x$, bar $=2 \mu \mathrm{m}$; D: $2500 \times$, bar $=10 \mu \mathrm{m}$.)
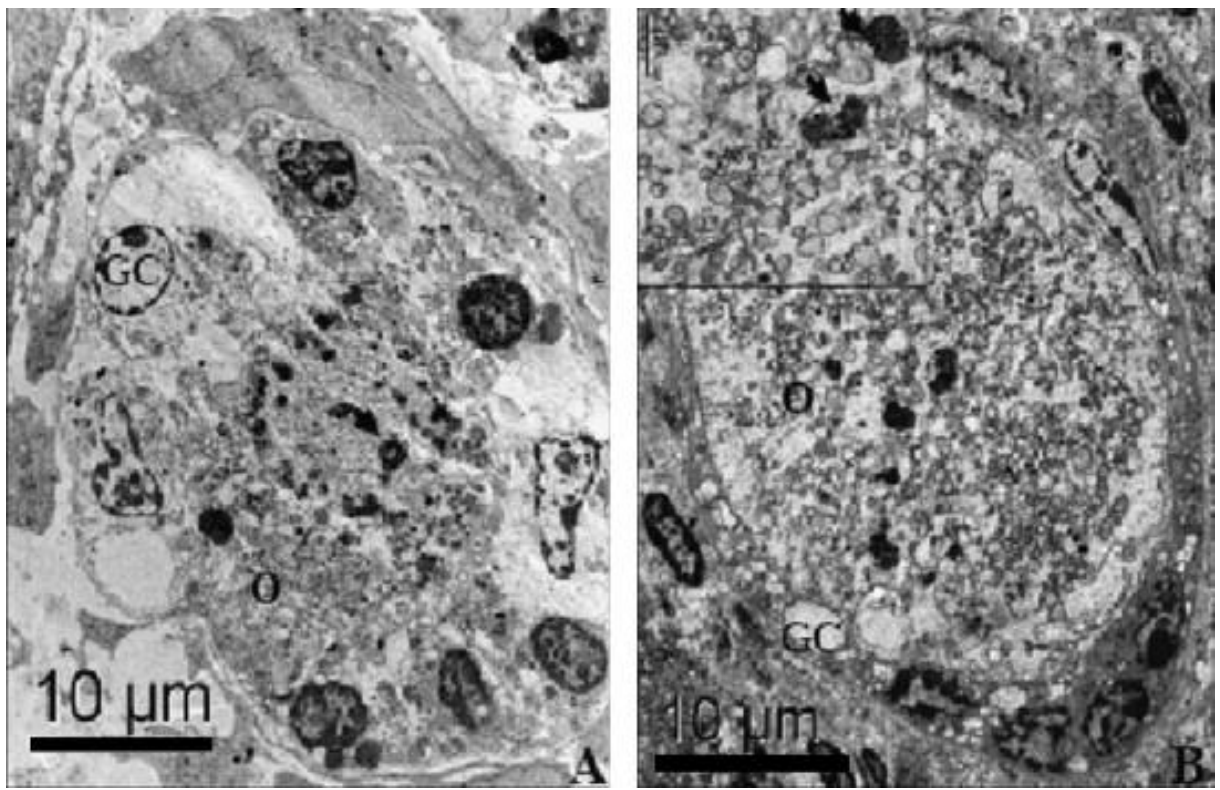

Fig. 4. Ultra-structural analysis of fresh ovarian tissue (control group)-A and frozen in presence of $1.5 \mathrm{M}$ DMSO using protocol 2-B. O, oocyte; $\mathrm{Nu}$, nucleus; GC, granulosa cell. Note that nucleus from 
degenerating oocyte is not distinguished and apoptotic bodies are present (arrows). (2500x, bar $=10$ $\mu \mathrm{m}$.

\section{Discussion}

Viability and ultra-structure of bovine ovarian preantral follicles were evaluated after exposure to or cryopreservation of ovarian tissue in the absence or presence of two concentrations $(1.5$ and $3.0 \mathrm{M}$ ) of glycerol, ethylene glycol, propanediol and dimethyl sulfoxide, either or not submitted to a previous cooling at $4{ }^{\circ} \mathrm{C}$ for $24 \mathrm{~h}$ in $0.9 \%$ saline solution.

It was not observed an effect of holding ovarian tissue in $0.9 \% \mathrm{NaCl}$ solution at $20^{\circ} \mathrm{C}$ for $1 \mathrm{~h}$ (protocol 1 ) or $4{ }^{\circ} \mathrm{C}$ for $24 \mathrm{~h}$ (protocol 2 ) on the follicular viability. In a previous work, we had preserved bovine ovarian fragments at $4{ }^{\circ} \mathrm{C}$ for up to $24 \mathrm{~h}$ in $0.9 \% \mathrm{NaCl}$ solution, and follicular viability percentages were similar to those observed in control ovaries (Celestino et al., 2007). Similar results were observed by Lucci et al. (2004b) after preservation of bovine ovarian tissue in coconut water solution at $4{ }^{\circ} \mathrm{C}$ for up to $18 \mathrm{~h}$. According to Roy and Treacy (1993), low metabolic rates, by maintaining preantral follicles at low temperatures, are essential for viability preservation of these follicles during preparation for routine laboratory procedures. Schmidt et al. (2003), evaluating the cooling effect during ovarian tissue transport followed by cryopreservation and xeno-transplantation on the human follicular survival, showed high survival rates of primordial follicles when transported at $0{ }^{\circ} \mathrm{C}$ for $4 \mathrm{~h}$, indicating that primordial follicles are resistant to low temperatures and ischemia before performing cryopreservation.

We also have shown that independently of the protocol used, the viability of bovine preantral follicles was not affected negatively when ovarian fragments were exposed to $1.5 \mathrm{M}$ EG, while only using protocol 1 , tissue exposed to $1.5 \mathrm{M}$ DMSO also presented similar viability percentages. When the rates of penetration of GLY, EG, DMSO and PROH are compared, reports present EG and DMSO as the best ovarian tissue cryoprotectants (Newton et al., 1998). Both cryoprotectants (EG and DMSO) have low molecular weight, which permits a faster penetration than that observed for $\mathrm{PROH}$ and GLY, which also explains our results. Therefore, previous studies have shown that during the equilibrium phase, after the addition of cryoprotectant media but prior to the freezing process, cells initially shrink as water flows out, and subsequently swell as water and cryoprotectant agent enter (Agca et al., 2002). Considering the toxicity and the osmotic effect of cryoprotectant agents, we suggest that both EG and DMSO can efficiently replace some water molecules in the cell but, after being stored at low temperatures for a long period, follicles still appearing viable became more sensitive to 
the in/out water and cryoprotectant flows, being the EG the less damaging cryoprotectant. Furthermore, the lower cryoprotective effect of DMSO is probably due to the formation of strong hydrophobic interactions with the apolar part of the membrane lipids, with consequent penetration of the sulfoxide into the bilayer, damaging biomembranes in a great extent (Markarian et al., 2004), which can be more deleterious in cells previously exposed to low temperatures. Also working with bovine preantral follicles, Lucci et al. (2004a) showed that EG is more toxic than DMSO or PROH. Differences obtained can be due to the used protocol, suggesting that the cryoprotectant effect is also depending on the method and ramps used during cooling and cryopreservation.

Previous cooling at $20^{\circ} \mathrm{C}$ for $1 \mathrm{~h}$ (protocol 1 ) followed by freezing in presence of $1.5 \mathrm{M}$ EG or DMSO, as well as storage at $4{ }^{\circ} \mathrm{C}$ for $24 \mathrm{~h}$ (protocol 2) before cryopreservation using 1.5 M EG did not reduce percentages of viable preantral follicles when compared to control (Table 1). In addition to the water replacement effect of intracellular cryoprotectants, these substances also reduce the amount of ice formed during cooling (Anchordoguy et al., 1991). This can be acquired by using cryoprotectants with high viscosity property like EG and PROH. However, PROH has been shown to have a variety of diverse metabolic effects such as cellular release of lactate and consequent acidification (Scholmerich et al., 1989), inhibition of carriermediated Na+-independent d-glucose uptake (Morshed et al., 1994) and inhibition of cell growth (Mochida and Gomyoda, 1987). On the other hand, DMSO has low viscosity, which does not modify the structure of the freeze concentrated material at rapid rates of cooling, offering poor protection for these cells.

The results of follicular viability obtained after using trypan blue staining were confirmed by ultra-structural analysis. Thus, TEM studies revealed that not only the basement membrane, but also important structures as mitochondria, endoplasmic reticulum, oocyte nuclei, and granulosa cells were preserved even after previous cooling and freezing-thawing. Regarding the presence of electron-dense granules, these findings were previously reported in normal bovine preantral follicles (Kacinskis et al., 2005).

In conclusion, bovine preantral follicles within ovarian tissue can be successfully cryopreserved using 1.5 M EG as cryoprotectant, even if the ovarian tissue is previously incubated at $4{ }^{\circ} \mathrm{C}$ for $24 \mathrm{~h}$ in $0.9 \%$ saline solution.

\section{Acknowledgements}

Juliana J.H. Celestino is a recipient of a grant from CAPES of Brazil and José Ricardo de Figueiredo is a recipient of a grant from CNPq of Brazil. 


\section{REFERENCES}

Agca, Y., Gilmore, J., Byers, M., Woods, E.J., Liu, J., Critser, J.K., 2002. Osmotic characteristics of mouse spermatozoa in the presence of extenders and sugars. Biol. Reprod. 67, 1493-1501.

Anchordoguy, T.J., Cecchini, C.A., Crowe, J.H., Crowe, L.M., 1991. Insights into the cryoprotective mechanism of dimethyl sulfoxide for phospholipid bilayers. Cryobiology 28, 467-473.

Candy, C.M., Wood, M.J., Whittingham, D.G., 1997. Effect of cryoprotectants on the survival of follicles in frozen mouse ovaries. J. Reprod. Fert. 110, 11-19.

Celestino, J.J.H., Santos, R.R., Matos, M.H.T., Costa, S.H.F., Silva, J.R.V., Martins, F.S., Rodrigues, A.P.R., Figueiredo, J.R., 2007. Preservation of bovine preantral follicles in $0.9 \%$ saline solution or TCM 199. Arq Bras Med Vet Zoo 59, 591-599.

Cocero, M.J., De la Espina, M.D., Aguilar, B., 2002. Ultrastructural characteristics of fresh and frozen-thawed ovine embryos using two cryoprotectants. Biol. Reprod. 66, 1244-1258.

Figueiredo, J.R., Hulshof, S.C.J., Van den Hurk, R., Ectors, F.J., Fontes, R.S., Nusgens, B., Bevers, M.M., Beckers, J.F., 1993. Development of a combined new mechanical and enzymatic method for the isolation of intact preantral follicles from fetal, calf and adult bovine ovaries. Theriogenology 40, 789-799.

Gandolfi, F., Paffoni, A., Brambilla, E.P., Bonetti, S., Brevini, T.A.L., Ragni, G., 2006. Efficiency of equilibrium cooling and vitrification procedures for the cryopreservation of ovarian tissue: comparative analysis between human and animal models. Fertil. Steril. 85, 1150-1156.

Kacinskis, M.A., Lucci, C.M., Luque, M.C.A., Bao, S.N., 2005. Morphometric and ultrastructural characterization of 'Bos indicus preantral follicles. Anim. Reprod. Sci. 87, 45-57.

Lucci, C.M., Kacinskis, M.A., Lopes, L.H.R., Rumpf, R., Bao, S.N., 2004a. Effect of different cryoprotectants on the 'structural preservation of follicles in frozen zebu bovine (Bos indicus) ovarian tissue. Theriogenology 61, 1101-1114.

Lucci, C.M., Kacinskis, M.A., Rumpf, R., Bao, S.N., 2004b. Effects of lowered temperatures and media on short-term ' preservation of zebu (Bos indicus) preantral ovarian follicles. Theriogenology 61, 461-472.

Markarian, S.A., Bonora, S., Bagramyan, K.A., Arakelyan, V.B., 2004. Glass-forming property of the system diethyl sulphoxide/water and its cryoprotective action on Escherichia coli survival. Cryobiology 49, 1-9.

Mochida, K., Gomyoda, M., 1987. Toxicity of ethylene glycol, diethylene glycol and propylene glycol to human cells in culture. Bull. Environ. Contam. Toxicol. 38, 151-153.

Morshed, K.M., Jain, S.K., Martin, K.E., 1994. Acute toxicity of propylene glycol: an assessment using cultured proximal tubule cells of human origin. Fundam. Appl. Toxicol. 23, 38-43.

Newton, H., Fisher, J., Arnold, J.R., Pegg, D.E., Faddy, M.J., Gosden, R.G., 1998. Permeation of human ovarian tissue with cryoprotective agents in preparation for cyopreservation. Hum. Reprod. 13, 376-378. 
Paynter, S.J., Copper, A., Fuller, B.J., Shaw, R.W., 1999. Cryopreservation of bovine ovarian tissue: structural normality of follicles after thawing and culture in vitro. Cryobiology 38, 301309.

Rodrigues, A.P.R., Amorim, C.A., Costa, S.H.F., Matos, M.H.T., Santos, R.R., Lucci, C.M., Bao, S.N., Ohashi, O.M., ' Figueiredo, J.R., 2004a. Cryopreservation of caprine ovarian tissue using dimethylsulphoxide and propanediol. Anim.Reprod. Sci. 84, 211-227.

Rodrigues, A.P.R., Amorim, C.A., Costa, S.H.F., Matos, M.H.T., Santos, R.R., Lucci, C.M., Bao, S.N., Figueiredo, J.R., '2004b. Cryopreservation of caprine ovarian tissue using glycerol and ethylene glycol. Theriogenology 61, 1009-1024.

Roy, S.K., Treacy, B.J., 1993. Isolation and long-term culture of human preantral follicles. Fertil. Steril. 59, 783-790. Santos, R.R., Tharasanit, T., Figueiredo, J.R., Van Haeften, T., Van den Hurk, R., 2006a. Preservation of caprine preantral follicle viability after cryopreservation in sucrose and ethylene glycol. Cell Tissue Res. 352, 523-531.

Santos, R.R., Rodrigues, A.P.R., Costa, S.H.F., Silva, J.R.V., Matos, M.H.T., Lucci, C.M., Bao, S.N., Van den Hurk, R.,' Figueiredo, J.R., 2006b. Histological and ultra-structural analysis of cryopreserved sheep preantral follicles. Anim. Reprod. Sci. 91, 249-263.

Santos, R.R., Tharasanit, T., Van Haeften, T., Figueiredo, J.R., Silva, J.R.V., Van den Hurk, R., 2007a. Vitrification of goat preantral follicles enclosed in ovarian tissue by using conventional and solid-surface vitrification methods. Cell Tissue Res. 327, 167-176.Santos, R.R., Van den Hurk, R., Rodrigues, A.P.R., Costa, S.H.F., Martins, F.S., Matos, M.H.T., Celestino, J.J.H., Figueiredo, J.R., 2007b. Effect of cryopreservation on viability, activation and growth of in situ and isolated ovine early-stage follicles. Anim. Reprod. Sci. 99, 53-64.

Schmidt, K.L.T., Ernst, E., Byskov, A.G., Andersen, A.N., Andersen, C.Y., 2003. Survival of primordial follicles following prolonged transportation of ovarian tissue prior to cryopreservation. Hum. Reprod. 18, 2654-2659.

Scholmerich, J., Kitamura, S., Miyai, K., 1989. Effects of propylene glycol on redox state of the perfused rat liver-a note of caution. Res. Exp. Med. 189, 39-42. 